\title{
Passive remediation of coalbed natural gas co-produced water using zeolite
}

\author{
Shashidhar Belbase ${ }^{a}$, Michael A. Urynowicz ${ }^{a}$, George F. Vance ${ }^{b}$, Mohan B. Dangi ${ }^{c, *}$ \\ a Department of Civil and Architectural Engineering, University of Wyoming, 1000 E. University Avenue, Laramie, WY 82071-2000, United States \\ ${ }^{\mathrm{b}}$ Department of Ecosystem Science and Management, University of Wyoming, 1000 E. University Avenue, Laramie, WY 82071-2000, United States \\ ${ }^{\mathrm{c}}$ Department of Geography, California State University, Fresno, 2555 E San Ramon Avenue, M/S SB 69, Fresno, CA 93740, United States
}

\begin{abstract}
:
Coalbed natural gas (CBNG) co-produced waters can contain sodium $\left(\mathrm{Na}^{+}\right)$concentrations that may be environmentally detrimental if discharged to receiving bodies of water or applied to land surfaces. A field demonstration and companion laboratory studies were conducted to evaluate the use of a Bear River zeolite (BR-zeolite) for mitigating impacts associated with $\mathrm{Na}^{+}$in CBNG waters. Bench-scale kinetic and adsorption isotherm studies were performed to determine both the rate and extent of sodium $\mathrm{Na}^{+}$adsorption and assess the effects of bicarbonate $\left(\mathrm{HCO}_{3}\right)$ and chloride $\left(\mathrm{Cl}^{-}\right)$anions. Results of these studies showed that the adsorption of $\mathrm{Na}^{+}$on BR-zeolite followed the Langmuir adsorption model with maximum adsorption equal to 21 and 18 $\mathrm{g} \mathrm{Na}^{+} / \mathrm{kg}$ zeolite with 0.0012 and $0.0006 \mathrm{~L} / \mathrm{mg}$ Langmuir co-efficients $\left(K_{\mathrm{L}}\right)$ for sodium bicarbonate and sodium chloride, respectively. The kinetics study indicated that the sorption of $\mathrm{Na}^{+}$was inversely related to the size of the zeolite particles with significantly greater adsorption for smaller particles. The field demonstration evaluated the effectiveness of BR-zeolite for mitigating infiltration losses from $\mathrm{Na}^{+}$in CBNG waters. The field site utilized 12 open boreholes, each installed to a depth of approximately $1.8 \mathrm{~m}$. Each borehole was lined with a $3.0 \mathrm{~m}$ long, $15 \mathrm{~cm}$ diameter schedule 40 PVC pipe and fitted with an automatic data logging pressure transducer for measuring water levels over time. The BR-zeolite was found to mitigate much of the deleterious effect that high sodium adsorption ratio $\left(\mathrm{SAR}=27\left(\mathrm{~mol} / \mathrm{m}^{3}\right)^{1 / 2}\right) \mathrm{CBNG}$ co-produced water had on soil permeabilities.
\end{abstract}

Keywords:

Sodium adsorption ratio (SAR), Groundwater infiltration, Hydraulic conductivity, Coalbed methane (CBM), Co-produced water

\section{Introduction}

The rapid expansion of coalbed natural gas (CBNG) production in the Powder River Basin (PRB) of northeast Wyoming has resulted in concerns related to the environmental impacts of CBNG coproduced water (DOE, 2008). From 1987 through 2011, the amount of water produced in the PRB was 1.2 billion cubic meters as compared to 135 billion cubic meters of natural gas during the same period (WOGCC, 2012). It is estimated that approximately 7 billion cubic meters of CBNG water will be produced by 2025 (BLM, 2002). Much of the CBNG co-produced water is characterized by high sodium adsorption ratios $\left(\mathrm{SAR}>12\left(\mathrm{~mol} / \mathrm{m}^{3}\right)^{1 / 2}\right)$ and specific electrical conductivities (EC) greater than $2 \mathrm{dS} / \mathrm{m}$ (Jackson and Reddy, 2007).

High SAR values are a potential concern regarding the management of CBNG co-produced water (Ganjegunte et al., 2005). The presence of $\mathrm{Na}^{+}$laden water in soil can cause common ion

*Corresponding author. Department of Geography, California State University, Fresno, 2555 E San Ramon Avenue, M/S SB 69, Fresno, CA 93740, United States. Tel.: p1 559278 4857; fax: p1 559278 7268. E-mail addresses: mdangi@csufresno.edu, garbagetalk@gmail.com (M.B. Dangi). exchange by replacing $\mathrm{Ca}^{2+}$ with $\mathrm{Na}^{+}$which can have a detrimentally effect on the soil's structure and permeability as a result of clay particle dispersion (Payne, 2004). High SAR values can also reduce the absorption of water by vegetation (Warrance et al., 2001). Researchers have reported that water from CBNG wells in the PRB is mostly dominated by $\mathrm{Na}^{+}$and bicarbonate $\left(\mathrm{HCO}_{3}^{-}\right)$ions with $\mathrm{pH}$ values ranging from 6.8 to 9.2 , EC ranging from 0.4 to $5.0 \mathrm{dS} / \mathrm{m}$, and SAR ranging from 5.0 to $70.0\left(\mathrm{~mol} / \mathrm{m}^{3}\right)^{1 / 2}$ (Rice et al., 2000; Ganjegunte et al., 2005; Jackson and Reddy, 2007; Johnston et al., 2008; Vance et al., 2008). Generally, SAR values between $\sim 10$ and $18\left(\mathrm{~mol} / \mathrm{m}^{3}\right)^{1 / 2}$ are considered a medium hazard, SAR values between 18 and $26\left(\mathrm{~mol} / \mathrm{m}^{3}\right)^{1 / 2}$ are a high hazard, and SAR values above $26\left(\mathrm{~mol} / \mathrm{m}^{3}\right)^{1 / 2}$ are deemed a very high hazard (Richards, 1954; Fetter, 2001).

The physical and chemical characteristics of topsoil play a significant role in the infiltration of CBNG co-produced waters. When CBNG co-produced water passes through topsoil the rate of water infiltration can be altered due to the salinity and sodicity of the water (Minhas et al., 1994; Johnston et al., 2008, 2011). Threshold laboratory values for electrolyte content in relation to the exchangeable sodium percentage (ESP) derived from laboratory 
studies have been used to predict the permeability effect of SAR on soils varying in texture, clay mineralogy, ionic exchange capacity, organic matter, and pH (Bresler et al., 1982; Quirk, 1971; Shainberg and Letey, 1984a,b; Pratt \& Saurez, 1990).

Due to their distinctive cation exchange capacities (CEC), zeolites have been utilized for ion-exchange, molecular sieve and catalytic processes. Zeolites have also been shown to be effective in removing ionic substances from polluted waters (Colella, 1996; Pansini, 1996; Mumpton, 1999; Wingenfelder et al., 2005). There are approximately 40 natural (Inglezakis, 2005) and 150 synthesized (Eyde and Holmes, 2006) zeolites that have the potential for use as an ion-exchange material. Zeolites have also been shown to effectively remove $\mathrm{Na}^{+}$from CBNG co-produced water (Zhao et al., 2009; Ganjegunte et al., 2011).

A field demonstration and companion laboratory studies were performed to evaluate zeolite for passive remediation of CBNG coproduced water. The aim of this research was to assess the effectiveness of Bear River zeolite (BR-zeolite) in passively remediating the harmful effects of CBNG co-produced water when applied to soil. Specific objectives of this study were to evaluate impacts that $\mathrm{HCO}_{3}^{-}$and chloride $\left(\mathrm{Cl}^{-}\right)$ions had on the adsorption of $\mathrm{Na}^{+}$and to analyse the effect of BR zeolite on the infiltration of CBNG coproduced water through the unsaturated zone. The findings of this study can be used to further assess the feasibility of zeolite lined evaporation ponds for the management and passive remediation of CBNG co-produced waters. To the best of our knowledge, this is the first field demonstration examining the effectiveness of zeolite for this purpose.

\section{Materials and methods}

Zeolites are hydrated aluminosilicates of alkaline and alkalineearth metals that are classified as analcime, chabazite, clinoptilolite, erionite, ferrierite, haulandite, laumontite, mordenite, and phillipsite minerals (Zhao et al., 2008). Bear River zeolite has a mineral composition of $85 \%$ clinoptilotlite, chemical composition of $3.47 \%$ potassium (K), $1.6 \% \mathrm{Ca}$, and less than $0.5 \%$ of Na (U.S. Antimony United States Antimony Corporation, 2009), surface area of $2.5 \mathrm{~km}^{2} / \mathrm{kg}$, bulk density of $881-991 \mathrm{~kg} / \mathrm{m}^{3}$, and CEC of $1.5-1.8 \mathrm{eq} /$ $\mathrm{kg}$. Two important properties of zeolite, as it pertains to water treatment, are surface area and CEC. The zeolite used in this study (Bear River Zeolite Company, Preston, ID) has been shown to reduce SAR from 30 to below $10\left(\mathrm{~mol} / \mathrm{m}^{3}\right)^{1 / 2}$ (Zhao et al., 2008; Ganjegunte et al., 2011). Surrogate CBNG waters were synthesized by dissolving $\mathrm{NaHCO}_{3}, \mathrm{KCl}, \mathrm{Na}_{2} \mathrm{SO}_{4}, \mathrm{NaCl}, \mathrm{CaCl}_{2}-2 \mathrm{H}_{2} \mathrm{O}, \quad \mathrm{MgCl}_{2}-6 \mathrm{H}_{2} \mathrm{O}$ and $\left(\mathrm{C}_{2} \mathrm{H}_{5} \mathrm{O}\right)_{4} \mathrm{Si}$ in both de-ionized (type I) and city water (type II). The waters used in the field demonstration included CBNG co-produced water and city water from Sheridan, Wyoming. The CBNG coproduced water came from a nearby water discharge outfall. The SAR and major cation concentrations of the various waters used for the different studies are summarized in Table 1.

\subsection{Adsorption isotherm study}

An adsorption isotherm study was performed using BR zeolite with sodium bicarbonate $\left(\mathrm{NaHCO}_{3}\right)$ and sodium chloride $(\mathrm{NaCl})$ solutions. The BR zeolite was crushed and sieved in order to provide a sample with a uniform particle size of $1.5-2.0 \mathrm{~mm}$. Forty (40) $\mathrm{ml}$ solutions of $\mathrm{NaHCO}_{3}$ and $\mathrm{NaCl}$ with $\mathrm{Na}^{+}$concentrations of 625 , $1,250,1,875,2,500,3750$ and $5000 \mathrm{mg} / \mathrm{L}$ as $\mathrm{Na}^{+}$were added to $50 \mathrm{ml}$ vials containing $5 \mathrm{~g}$ of BR-zeolite. Each bottle was then tightly capped, placed on a mechanical horizontal rotator (Barnsted Thermolyne, Model 4152110), and rotated at $60 \mathrm{rpm}$ for a period of two days $(48 \mathrm{~h})$ at ambient temperature $\left(\sim 22^{\circ} \mathrm{C}\right)$ until chemical equilibrium was reached. The supernatant solutions were then
Table 1

SAR and $\mathrm{Na}^{+}, \mathrm{Ca}^{2+}$, and $\mathrm{Mg}^{2+}$ concentrations for the different waters used in the study.

\begin{tabular}{|c|c|c|c|c|}
\hline \multirow[t]{2}{*}{ Water type } & \multicolumn{3}{|c|}{ Concentration of Cations } & \multirow{2}{*}{$\begin{array}{l}\text { SAR } \\
\left(\mathrm{mol} / \mathrm{m}^{3}\right)^{1 / 2}\end{array}$} \\
\hline & $\begin{array}{l}\mathrm{Na}^{+} \\
\left(\mathrm{mol} / \mathrm{m}^{3}\right)\end{array}$ & $\begin{array}{l}\mathrm{Ca}^{2+} \\
\left(\mathrm{mol} / \mathrm{m}^{3}\right)\end{array}$ & $\begin{array}{l}\mathrm{Mg}^{2+} \\
\left(\mathrm{mol} / \mathrm{m}^{3}\right)\end{array}$ & \\
\hline Tap water in the lab, UW & 1.78 & 0.55 & 0.33 & 1.90 \\
\hline City tap water in Sheridan, WY & 0.63 & 0.14 & 0.04 & 1.47 \\
\hline $\begin{array}{l}\text { Synthetic CBNG co-produced } \\
\text { water (type I) }\end{array}$ & 19.63 & 0.80 & 0.43 & 17.70 \\
\hline $\begin{array}{l}\text { Synthetic CBNG co-produced } \\
\text { water (type II) }\end{array}$ & 17.85 & 0.25 & 0.10 & 30.17 \\
\hline $\begin{array}{l}\text { CBNG co-produced water in } \\
\text { the field study area }\end{array}$ & 13.03 & 0.14 & 0.09 & 27.07 \\
\hline
\end{tabular}

filtered $(0.20 \mu \mathrm{m})$ and analyzed for $\mathrm{Na}^{+}$using an Inductively Coupled Plasma (ICP) Spectroscopy (Thermo Jarrell Ash, Model P300).

\subsection{Adsorption kinetics study}

$\mathrm{A} \mathrm{Na}^{+}$adsorption kinetics study was conducted using a batch equilibration technique (Zhao et al., 2008, 2009) and four different zeolite size fractions (1.3-1.5, 1.5-1.7, 1.7-2.0, and $2.0-2.5 \mathrm{~mm}$ ). Twenty grams of BR zeolite from each particle size fraction was added to $500 \mathrm{ml}$ of synthetic CBNG water (type I) in reaction vessels and the solutions were mixed at $60 \mathrm{rpm}$ using a mechanical stirrer (Phipps \& Bird, Model No. 300). The vessels were sampled at 0, 30, $60,120,180,300,420$, and $660 \mathrm{~min}$ by collecting a $1 \mathrm{ml}$ aliquot of solution that was filtered through a disc filter (SFCA/PF, $0.20 \mu \mathrm{m}$ ) attached to a syringe. The samples were then diluted to $25 \mathrm{ml}$ with DI water and analyzed for $\mathrm{Na}^{+}, \mathrm{Ca}^{2+}$, and $\mathrm{Mg}^{2+}$ using ICP Spectroscopy.

\subsection{Field demonstration}

The field demonstration was designed to evaluate the following experimental conditions in triplicate: (1) city water without zeolite, (2) city water with zeolite, (3) CBNG water without zeolite, and (4) CBNG water with zeolite. The field demonstration site was located adjacent to the University of Wyoming Research and Extension Center in Sheridan, Wyoming. A private drilling company drilled twelve boreholes in three rows (four to a row). The boreholes in each row were located approximately $8 \mathrm{~m}$ from each other and the rows were spaced approximately $8 \mathrm{~m}$ apart. Each borehole was approximately $1.8 \mathrm{~m}$ deep and had a diameter slightly greater than $20 \mathrm{~cm}$. Falling head permeameters were constructed using $3 \mathrm{~m}$ sections of $15 \mathrm{~cm}$ diameter schedule 40 polyvinyl chloride (PVC) pipe. The pipes were emplaced in the boreholes by hydraulically advancing each one approximately $5 \mathrm{~cm}$ into the soil. Since the boreholes were only $1.8 \mathrm{~m}$ deep this resulting in a $\sim 1.2 \mathrm{~m}$ riser. The annulus around each pipe was filled with bentonite effectively sealing them off from the surface.

Six of the twelve boreholes were randomly selected to receive $3 \mathrm{~kg}$ of BR zeolite, which formed a permeable reactive barrier of approximately $8-10 \mathrm{~cm}$ in thickness directly above the soil. Based on the results from the adsorption isother study this amount of zeolite can treat approximately $180 \mathrm{~L}$ of CBNG co-produced water with an SAR value of $30\left(\mathrm{~mol} / \mathrm{m}^{3}\right)^{1 / 2}$ reducing it to below $10(\mathrm{~mol} /$ $\left.\mathrm{m}^{3}\right)^{1 / 2}$. The remaining six boreholes did not receive zeolite and served as controls. Automatic data logging pressure transducers (Level TROLL 500, In-Situ, Inc.) were calibrated and installed in the bottom of each borehole to measure water levels with time. A separate pressure transducer was attached to the outside of one of the risers to record ambient temperature and barometric pressure. 


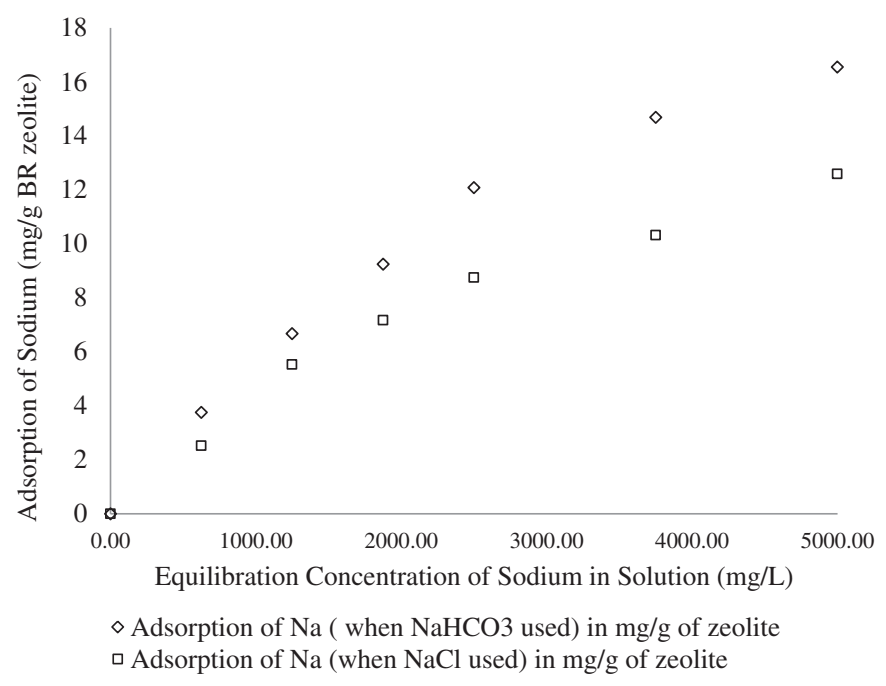

Fig. 1. Sorption of $\mathrm{Na}^{+}$by $\mathrm{BR}$ zeolite at different equilibrium concentrations in $48 \mathrm{~h}$ for $\mathrm{NaHCO}_{3}$ and $\mathrm{NaCl}$ solutions.

Approximately $53 \mathrm{~L}$ of CBNG water was used to fill six of the boreholes (three with zeolite and three without) and the other six were filled with $\sim 53 \mathrm{~L}$ of tap water. Once the boreholes were filled they were covered with plastic to prevent the addition of rainwater and reduce evaporation. After a period of 38 days the boreholes were refilled with the appropriate water (Phase II). Following the completion of the field demonstration intact soil cores were collected from the bottom of each of the boreholes using $5 \mathrm{~cm}$ diameter by $1.2 \mathrm{~m}$ long polyethylene pipes. Soils corresponding to depths of $0-5,5-15,15-30,55-65$, and $95-105 \mathrm{~cm}$ were extruded from the cores and composited for further analysis. Approximately $100 \mathrm{~g}$ of the composited soils were used to prepare saturated paste extracts (USDA, 1954). The saturated paste extracts were further diluted and analyzed for major cations $\left(\mathrm{Na}^{+}, \mathrm{Ca}^{2+}\right.$, and $\left.\mathrm{Mg}^{2+}\right)$, EC and $\mathrm{pH}$.

\section{Results}

\subsection{Adsorption isotherm}

Adsorption of $\mathrm{Na}^{+}(\mathrm{mg} / \mathrm{g})$ by BR zeolite was determined for different equilibrium concentrations $(\mathrm{mg} / \mathrm{L})$ of $\mathrm{Na}^{+}$in $\mathrm{NaHCO}_{3}$ and $\mathrm{NaCl}$ solutions (Fig. 1). Results indicated that sorption of $\mathrm{Na}^{+}$in $\mathrm{BR}-$ zeolite was higher for $\mathrm{NaHCO}_{3}$ than $\mathrm{NaCl}$ for all initial concentrations of $\mathrm{Na}^{+}(625,1,250,2,500,3,750$, and $5000 \mathrm{mg} / \mathrm{L})$. The isotherm curves revealed that the $\mathrm{Na}^{+}$adsorption could be well described using the Langmuir equation (Eq. (1)):

$q=\frac{q_{\max } K C}{1+K C}$

where $q$ is the $\mathrm{Na}^{+}$adsorbed $(\mathrm{mg} / \mathrm{g}), q_{\max }$ is the maximum adsorption capacity $(\mathrm{mg} / \mathrm{g}$ ) of the solid phase, $K$ is the Langmuir constant, and $\mathrm{C}$ is concentration $(\mathrm{mg} / \mathrm{L})$ of $\mathrm{Na}^{+}$in the solution at equilibrium. Upon rearranging Equation (1), Equation (2) is obtained:

Table 2

Maximum adsorption of sodium, Langmuir Coefficients and R squared values.

\begin{tabular}{llll}
\hline Reaction & $q_{\max }(\mathrm{mg} / \mathrm{g})$ & $K$ & $R^{2}$ \\
\hline BR zeolite with $\mathrm{NaHCO}_{3}$ & 21 & 0.0012 & 0.99 \\
BR zeolite with $\mathrm{NaCl}$ & 18 & 0.0006 & 0.96 \\
\hline
\end{tabular}

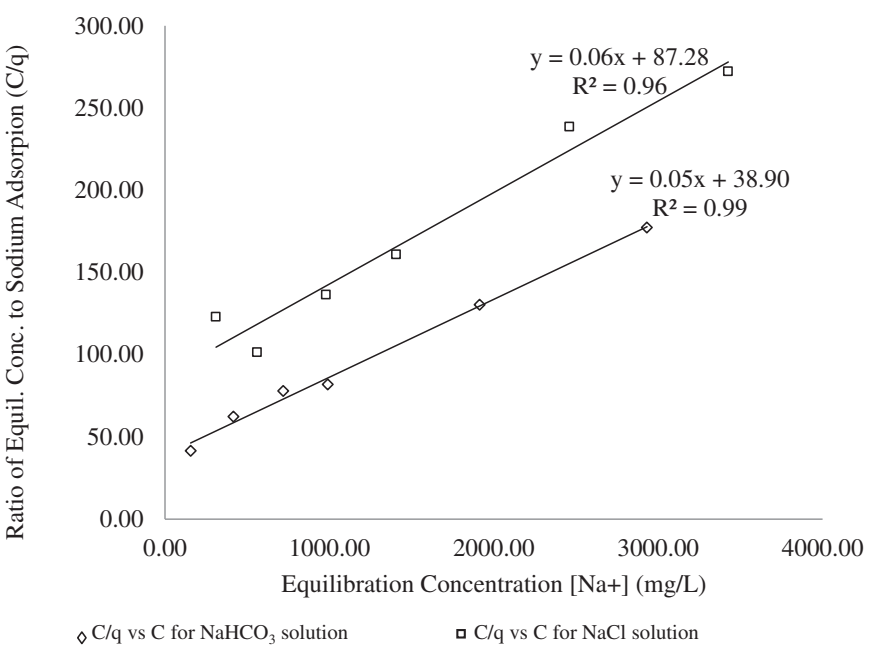

Fig. 2. Langmuir Adsorption Isotherm models for adsorption of $\mathrm{Na}^{+}$by $\mathrm{BR}$ zeolite from $\mathrm{NaHCO}_{3}$ and $\mathrm{NaCl}$ solutions at different equilibration concentrations.

$\frac{C}{q}=\frac{1}{K q_{\max }}+\frac{C}{q_{\max }}$

By plotting $C / q$ vs. $C$, the slope of the line $\left(1 / q_{\max }\right)$ was used to determine $q_{\max }$ and the intercept $\left(1 /\left(\mathrm{Kq}_{\max }\right)\right)$ used to determine $\mathrm{K}$. The values of $q_{\max }, K$, and $R^{2}$ for $\mathrm{NaHCO}_{3}$ and $\mathrm{NaCl}$ were calculated (Table 2) using the equations for a straight line (Fig. 2) and the maximum sorption capacities of 18 and $21 \mathrm{~g} / \mathrm{kg}$ were determined for the $\mathrm{NaCl}$ and $\mathrm{NaHCO}_{3}$ solutions, respectively. The adsorption of $\mathrm{Na}^{+}$by BR-zeolite at different equilibration concentrations was also fitted to the Freundlich equation:

$X / m=K_{\mathrm{f}} C_{\mathrm{e}}^{1 / n}$

where $X$ is mass of adsorbate $(\mathrm{mg}), m$ is mass of adsorbent $(\mathrm{g}), K_{\mathrm{f}}$ is Freundlich coefficient, $C_{\mathrm{e}}$ is the equilibrium concentration $(\mathrm{mg} / \mathrm{L})$, and $1 / n$ is a constant. This equation was also converted into linear form to determine the values of $n, K_{\mathrm{f}}$, and $R^{2}$ for $\mathrm{NaHCO}_{3}$ and $\mathrm{NaCl}$ (See Table 3).

The coefficient of determination $\left(R^{2}\right)$ for $\mathrm{NaHCO} 3$ and $\mathrm{NaCl}$ indicated that both models fit the adsorption of $\mathrm{Na}^{+}$by BR zeolite well although the Langmuir model was slightly better. Similar results were shown by Zhao et al. (2008, 2009). The Langmuir and Freundlich adsorption coefficients were greater for $\mathrm{NaHCO}_{3}$ than $\mathrm{NaCl}$. It is likely that the larger adsorption coefficients and maximum adsorption $\left(q_{\max }\right)$ values for $\mathrm{NaHCO}_{3}$ can be attributed to the precipitation of $\mathrm{Ca}^{2+}$ due to the formation of calcium carbonate $\left(\mathrm{CaCO}_{3}\right)$ and its release from zeolite into the solution. The formation of $\mathrm{CO}_{2}$ and resulting decrease in solution $\mathrm{pH}$ may also contribute to increased $\mathrm{Ca}^{2+}$ and $\mathrm{Mg}^{2+}$ desorption resulting in greater adsorption of $\mathrm{Na}^{+}$on exchange sites.

The following chemical and physical processes result in the cation exchange reaction between $\mathrm{Na}^{+}$and zeolite:

$\mathrm{NaCl} \leftrightarrow \mathrm{Na}^{+}+\mathrm{Cl}^{-}$

Table 3

Freundlich constants $n, K_{\mathrm{f}}$, and $R$ squared values.

\begin{tabular}{llll}
\hline Reaction & $n$ & $K_{\mathrm{f}}$ & $R^{2}$ \\
\hline BR zeolite with $\mathrm{NaHCO}_{3}$ & 1.93 & 0.29 & 0.96 \\
BR zeolite with $\mathrm{NaCl}$ & 1.64 & 0.08 & 0.92 \\
\hline
\end{tabular}



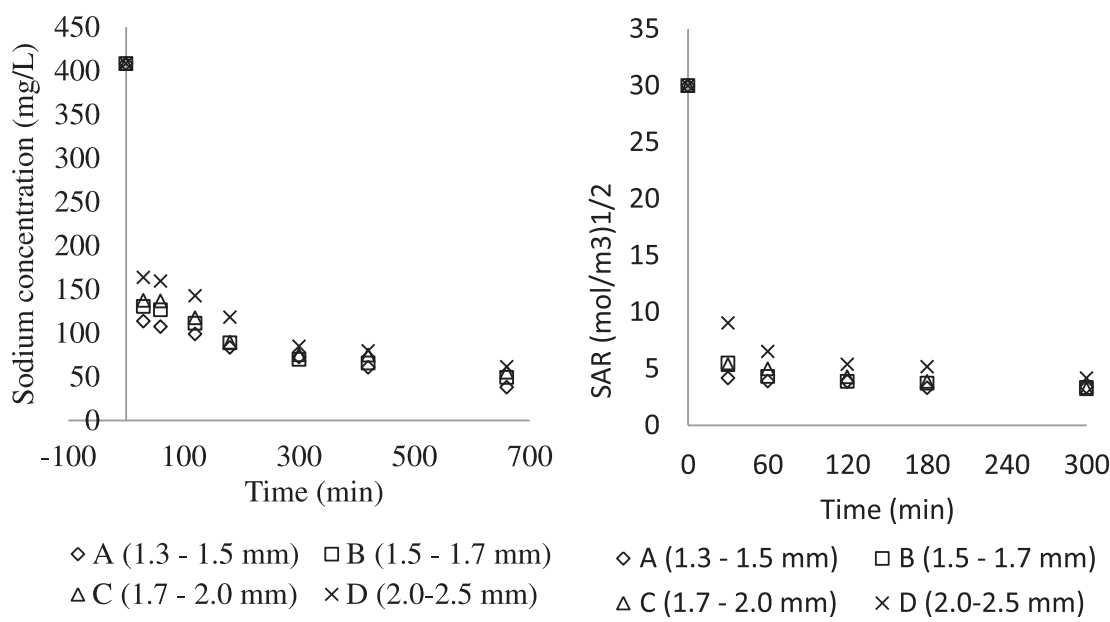

Fig. 3. Change of $\mathrm{Na}^{+}$concentration $(\mathrm{mg} / \mathrm{L})$ and $\mathrm{SAR}\left(\mathrm{mol} / \mathrm{m}^{3}\right)^{1 / 2}$ with time (min) for BR zeolite particle sizes $1.3-1.5 \mathrm{~mm}, 1.5-1.7 \mathrm{~mm}, 1.7-2.0 \mathrm{~mm}$, and $2.0-2.5 \mathrm{~mm}$.

$$
\begin{aligned}
& 2 \mathrm{Na}^{+}+\mathrm{Ca}-\text { Zeolite } \leftrightarrow \mathrm{Ca}^{2+}+\mathrm{Na}^{2}-\text { Zeolite } \\
& \mathrm{Ca}^{2+}+2 \mathrm{Cl}^{-} \leftrightarrow \mathrm{CaCl}_{2} \text { (soluble) } \\
& \mathrm{NaHCO}_{3} \leftrightarrow \mathrm{Na}^{+}+\mathrm{HCO}_{3}^{-} \\
& 2 \mathrm{Na}^{+}+\mathrm{Ca}-\text { Zeolite } \rightarrow \mathrm{Ca}^{2+}+\mathrm{Na}^{2}-\text { Zeolite } \\
& \mathrm{Ca}^{2+}+2 \mathrm{HCO}_{3}^{-} \rightarrow \mathrm{CaCO}_{3} \text { (solid) } \downarrow+\mathrm{H}_{2} \mathrm{O}+\mathrm{CO}_{2}
\end{aligned}
$$

Ion exchange reactions continued until an equilibrium state was reached. It is suspected that the equilibrium condition occurred earlier with $\mathrm{NaCl}$ because the concentration of $\mathrm{Ca}^{2+}$ in solution (desorbed from the zeolite) increased with time and did not form a precipitate. However, $\mathrm{Ca}^{2+}$ desorbed from zeolite in the presence of $\mathrm{NaHCO}_{3}$ can precipitate (Equations (7)-(9)) which keeps the concentration of $\mathrm{Ca}^{2+}$ in solution lower, thus shifting equilibria to the right.

\subsection{Adsorption kinetics}

As shown in Fig. 3, greater $\mathrm{Na}^{+}$sorption rates for the surrogated CBNG co-produced water (Type I) occurred with smaller sized zeolite particles. Although Zhao et al. (2008) stated that in porous materials such as zeolites the majority of reactive sites are on internal surfaces, adsorption was found to be directly related to the particle surface area. The greatest efficiency was found with the smallest particle size $(1.3-1.5 \mathrm{~mm})$, which removed about $72 \%$ of $\mathrm{Na}^{+}$in the first 30 min of reaction (Table 4). The SAR value of the simulated CBNG water was reduced from 30 to below $10\left(\mathrm{~mol} / \mathrm{m}^{3}\right)^{1 /}$ 2 in the first $30 \mathrm{~min}$ of reaction, resulting in SAR values of 4.2, 5.5, 5.4 and $9.0\left(\mathrm{~mol} / \mathrm{m}^{3}\right)^{1 / 2}$ corresponding to zeolite particle sizes of $1.3-1.5,1.5-1.7,1.7-2.0$, and $2.0-2.5 \mathrm{~mm}$, respectively (Fig. 3 and

Table 4

Initial and final SAR values and $\mathrm{Na}^{+}$removal percentage as a function of BR zeolite particle sizes after $30 \mathrm{~min}$.

\begin{tabular}{lcccc}
\hline Particle size $(\mathrm{mm})$ & $1.3-1.5$ & $1.5-1.7$ & $1.7-2.0$ & $2.0-2.5$ \\
\hline Initial SAR $\left(\mathrm{mol} / \mathrm{m}^{3}\right)^{1 / 2}$ & 30.0 & 30.0 & 30.0 & 30.0 \\
Final SAR $\left(\left(\mathrm{mol} / \mathrm{m}^{3}\right)^{1 / 2}\right.$ after 30 min) & 4.2 & 5.5 & 5.4 & 9.0 \\
$\mathrm{Na}^{+}$removal percentage & 72 & 68 & 66 & 59 \\
$\quad(\%$ after 30 min) & & & &
\end{tabular}

Table 4). These results are comparable to Huang and Natrajan (2006) who reported a similar relationship among adsorption rates and particle size. In addition, the diffusional resistance to mass transport within larger particle-sized zeolites is generally higher than that of smaller particle-sized zeolites (Airoldi and Critter, 2003).

\subsection{Field demonstration}

Daily water levels within the boreholes and the amount of water infiltrated were plotted for each of the experimental conditions over time (Fig. 4). As shown the water level decreased at a faster rate for the boreholes containing CBNG co-produced water and zeolite than for those containing CBNG co-produced water without zeolite. The slow rate of change for the boreholes containing CBNG co-produced water without zeolite as compared to other experimental conditions suggests that $\mathrm{Na}^{+}$had a detrimental effect on soil infiltration but that zeolite was able to mitigate at least some of the impact. As shown in Fig. 5, the average maximum $\mathrm{Na}^{+}$loadings throughout the field demonstration were $0.60 \mathrm{~g}, 1.31 \mathrm{~g}, 6.94 \mathrm{~g}$, and $28.5 \mathrm{~g}$ of $\mathrm{Na}^{+}$for the boreholes with city water and zeolite, city water without zeolite, CBNG co-produced water without zeolite, and CBNG co-produced water with zeolite, respectively. Based on

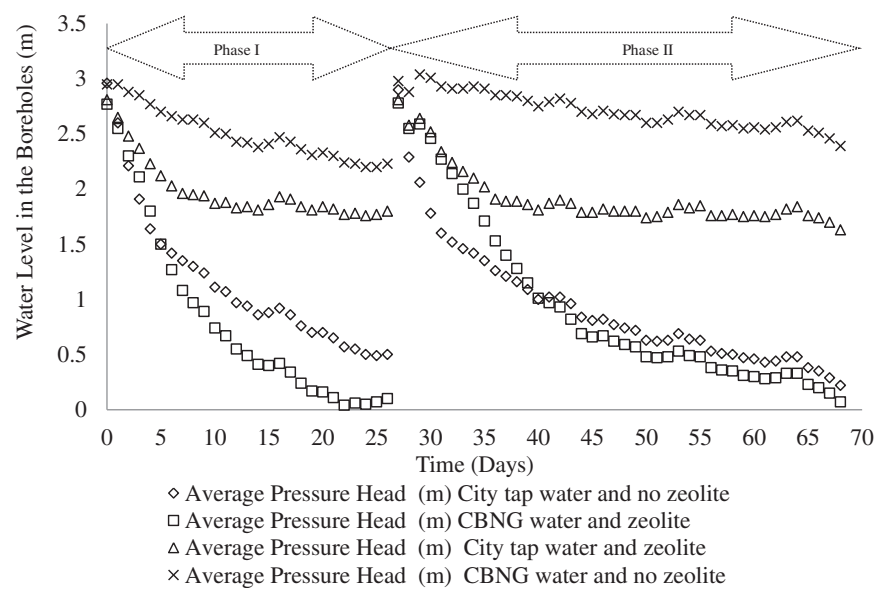

Fig. 4. Daily water levels $(\mathrm{m})$ in boreholes of different experimental conditions over time (days). Phase I ended on day 27 and Phase II began on day 28 and ended on day 68. 


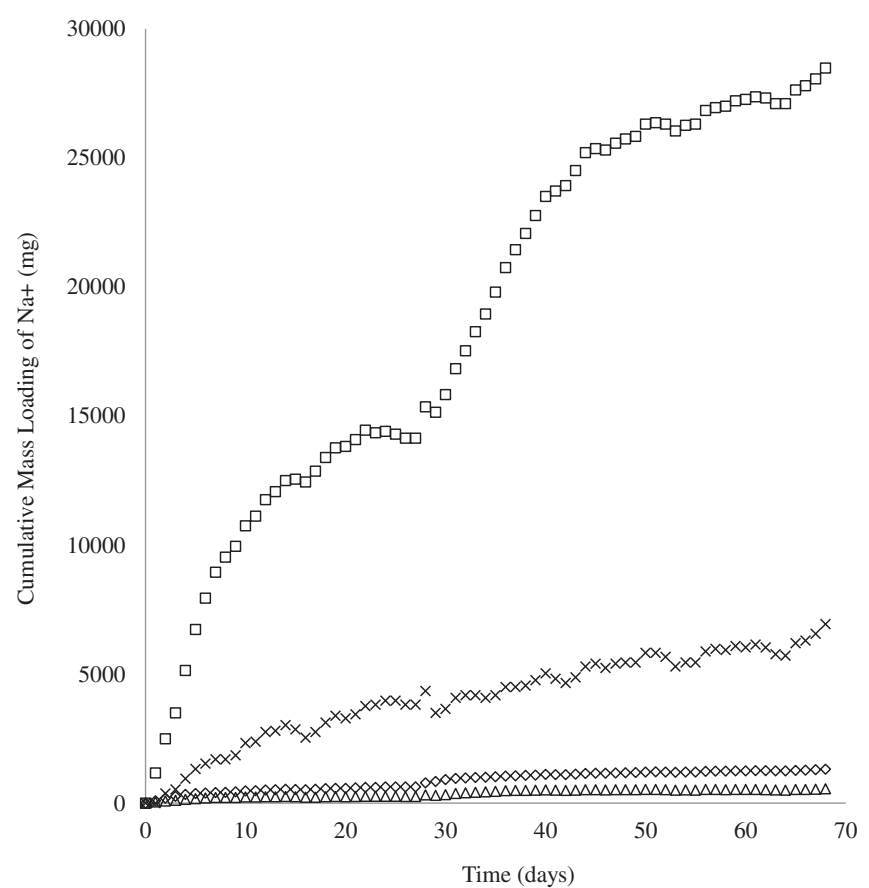

$\diamond$ Cum. mass loading (mg) of $\mathrm{Na}+$ through boreholes with city tap water and no zeolite

$\square$ Cum. mass loading $(\mathrm{mg})$ of $\mathrm{Na}+$ through boreholes with $\mathrm{CBNG}$ coproduced water and zeolite

$\Delta$ Cum. mass loading $(\mathrm{mg})$ of $\mathrm{Na}+$ through boreholes with city tap water and zeolite

$\times$ Cum. mass loading $(\mathrm{mg})$ of $\mathrm{Na}+$ through boreholes with $\mathrm{CBNG}$ coproduced water and no zeolite

Fig. 5. Cumulative mass loading ( $\mathrm{mg}$ ) of $\mathrm{Na}+$ through boreholes of different experimental conditions over time (days).

Table 5

Mass loading of $\mathrm{Na}^{+}$through boreholes.

\begin{tabular}{lll}
\hline \multicolumn{2}{l}{ Experimental conditions } & $\mathrm{Na}^{+}(\mathrm{mg})$ \\
\hline City tap water & Boreholes with zeolite & 559 \\
& Boreholes without zeolite & 1312 \\
CBNG coproduced & Boreholes with zeolite & 28500 \\
$\quad$ water & Boreholes without zeolite & 6936 \\
$\begin{array}{l}\text { Zeolite capacity } \\
(3000 \text { g) }\end{array}$ & From Langmuir model & $54000-63000$ \\
Impact of zeolite & Mass of $\mathrm{Na}^{+}$that was possibly & $50 \%$ (approximately) \\
& absorbed by the zeolite & \\
\hline
\end{tabular}

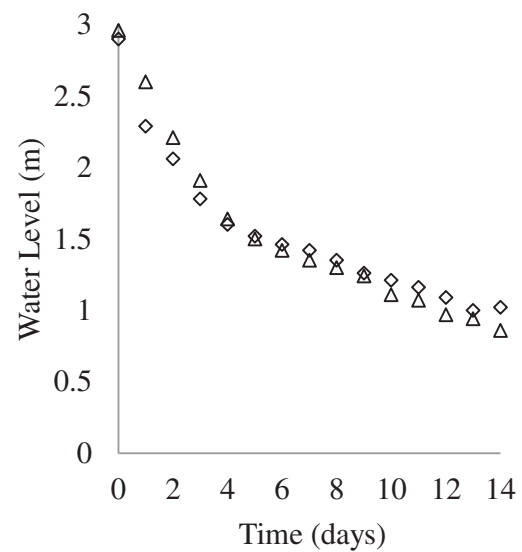

$\triangle$ City tap water and no zeolite Phase I

$\diamond$ City tap water and no zeolite Phase II the results from the $\mathrm{NaHCO}_{3}$ adsorption isotherm study, $3 \mathrm{~kg}$ of BRzeolite can adsorb approximately $63 \mathrm{~g}$ of $\mathrm{Na}^{+}$. The mass loading of $\mathrm{Na}^{+}$through boreholes with CBNG co-produced water and zeolite was greater than the mass loading through boreholes with CBNG co-produced water without zeolite by approximately $76 \%$ (Table 5 ). The results indicate that zeolite effectively mitigated some of the negative infiltration effects of high SAR (CBNG co-produced water). However, the presence of zeolite appears to have resulted in slightly lower permeability for the low SAR water (city water).

The water levels in the city water boreholes without zeolite had similar daily water levels indicating that the infiltration of water through the boreholes did not change significantly between Phase I and II (Fig. 6). Consequently, it appears that the SAR of the city water $\left(\mathrm{SAR}=1.47\left(\mathrm{~mol} / \mathrm{m}^{3}\right)^{1 / 2}\right)$ had little effect on the soil's permeability. Although the water levels in the boreholes with CBNG co-produced water and zeolite were slightly lower in Phase II as compared to Phase I, the slopes of the lines (i.e., infiltration rates) were very similar to the city water boreholes without zeolite. The water levels in the boreholes with city water and zeolite were also similar in Phases I and II (Fig. 7). However, as previously mentioned the infiltration rates were slightly lower than the city water boreholes without zeolite. Although a slight reduction in permeability was expected it is possible that the condition was exacerbated by the clogging of soil pores by small zeolite particles thereby reducing the porosity of the soil's upper layer (Al-Busaidi et al., 2008). The infiltration rates for the boreholes with CBNG co-produced water with zeolite were much greater than the infiltration rates for the boreholes with CBNG co-produced water without zeolite. Water levels in the CBNG co-produced water boreholes without zeolite indicate a significant reduction in soil permeability from Phase I to II. The Phase I results indicate an average of $79 \%$ of the water from the boreholes with CBNG co-produced water and zeolite had infiltrated into the soil in 14 days, approximately four times as much water as the boreholes without zeolite (19\%). The Phase II results indicated a loss of water from the boreholes with CBNG coproduced water and zeolite of $60 \%$, approximately 10 times the loss of water from the boreholes with CBNG co-produced water without zeolite (6\%) during the same period of time. A statistical analysis of the hydraulic conductivity data indicates a significant difference (95 CI) with respect to the means for Phase I and II and a significant difference with respect to the variances for Phase I.

The soil paste extract data for SAR, EC, and $\mathrm{pH}$ is summarized in Table 6. Bivariate correlations of SAR, EC, and $\mathrm{pH}$ found that there was only a moderate negative correlation between SAR and EC

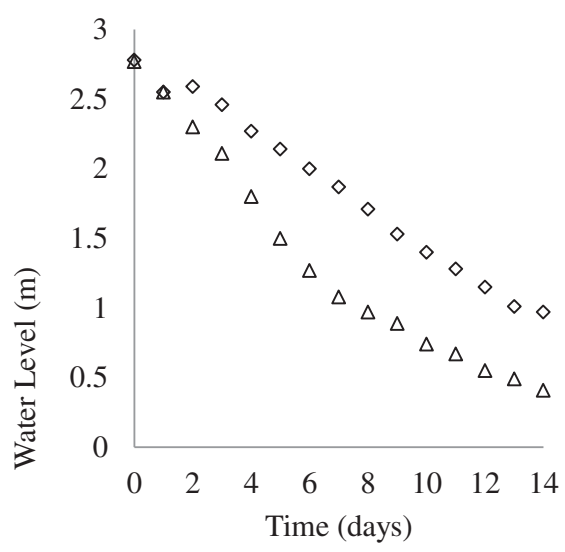

$\triangle \mathrm{CBNG}$ and zeolite Phase I

$\diamond$ CBNG and zeolite Phase II

Fig. 6. A Phase I and II comparison of water levels in boreholes with city tap water (left) and CBNG co-produced water (right) and no zeolite as a function of time. 


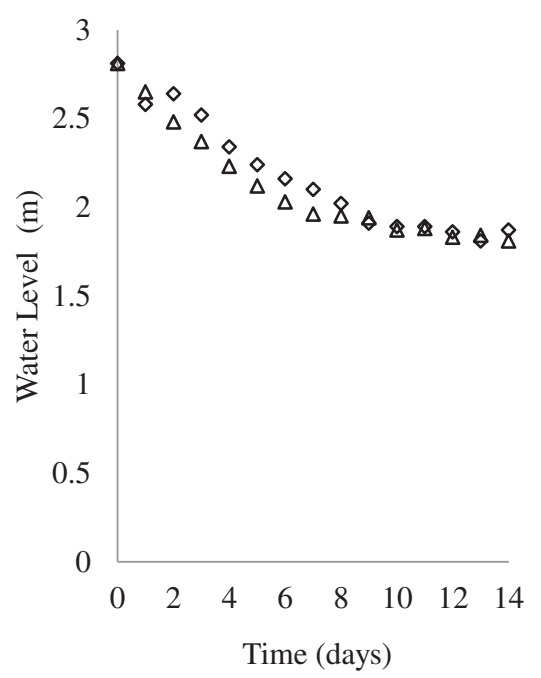

$\Delta$ City tap water and zeolite Phase I

$\diamond$ City tap water and zeolite Phase II

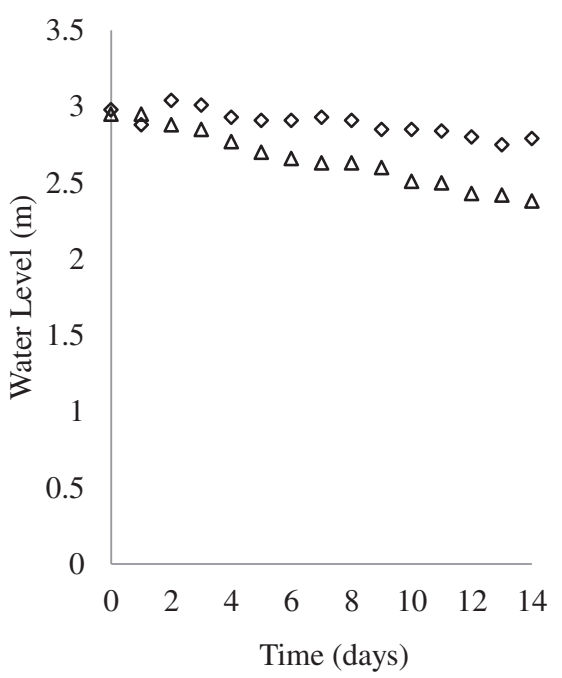

$\triangle \mathrm{CBNG}$ coproduced water and no zeolite Phase I

$\diamond \mathrm{CBNG}$ coproduced water and no zeolite Phase II

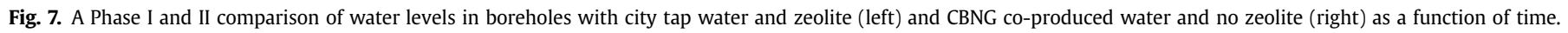

$(r=-0.62)$ and EC and $\mathrm{pH}(r=-0.68)$. However, SAR and $\mathrm{pH}$ $(r=0.96)$ showed a strong positive correlation (both SAR and $\mathrm{pH}$ decreased with depth while EC increased with depth). Fig. 8 shows that SAR decreased with depth for each of the experimental conditions, except for the CBNG co-produced water boreholes with zeolite, which showed slightly greater values for $5-15 \mathrm{~cm}(\mathrm{SAR}=8.8(\mathrm{~mol} /$ $\left.\left.\mathrm{m}^{3}\right)^{1 / 2}\right)$ than $0-5 \mathrm{~cm}\left(\mathrm{SAR}=6.4\left(\mathrm{~mol} / \mathrm{m}^{3}\right)^{1 / 2}\right)$. The higher SAR near the surface resulted from the mass loading of $\mathrm{Na}^{+}$and its accumulation in the soil due to cation exchange (Burrow et al., 2002; Ganjegunte et al., 2004). The data also shows that SAR values for the CBNG co-produced water boreholes without zeolite were higher than the boreholes with zeolite, except at the 5-15 cm depth. The EC results in Fig. 9 show the opposite correlation for EC which increased with depth for all of the boreholes except the city water boreholes without zeolite from 0 to 5 to $5-15 \mathrm{~cm}(1.6 \mathrm{dS} / \mathrm{m}$ to $1.2 \mathrm{dS} / \mathrm{m})$.

Table 6

Case summaries of field experimental conditions.

\begin{tabular}{|c|c|c|c|c|}
\hline \multicolumn{2}{|l|}{ Experimental conditions } & \multicolumn{3}{|c|}{ Experimental results } \\
\hline Treatment & Depth $(\mathrm{cm})$ & $\begin{array}{l}\text { SAR } \\
\left(\mathrm{mol} / \mathrm{m}^{3}\right)^{1 / 2}\end{array}$ & $\mathrm{EC}(\mathrm{dS} / \mathrm{m})$ & $\mathrm{pH}$ \\
\hline \multirow{5}{*}{$\begin{array}{l}\text { CBNG coproduced water } \\
\text { but no zeolite }\end{array}$} & $0-5$ & 8.3 & 0.9 & 7.4 \\
\hline & $5-15$ & 7.4 & 0.9 & 7.3 \\
\hline & $15-30$ & 5.8 & 1.3 & 7.1 \\
\hline & $55-65$ & 1.6 & 1.4 & 6.3 \\
\hline & $95-105$ & 1.1 & 1.6 & 6.1 \\
\hline \multirow{5}{*}{$\begin{array}{l}\text { CBNG coproduced water } \\
\text { and zeolite }\end{array}$} & $0-5$ & 6.4 & 0.8 & 7.3 \\
\hline & $5-15$ & 8.8 & 1.1 & 7.3 \\
\hline & $15-30$ & 2.9 & 1.4 & 6.9 \\
\hline & $55-65$ & 1.0 & 1.9 & 6.1 \\
\hline & $95-105$ & 0.8 & 2.2 & 6.1 \\
\hline \multirow[t]{5}{*}{ City tap water but zeolite } & $0-5$ & 0.6 & 0.7 & 6.3 \\
\hline & $5-15$ & 0.5 & 1.4 & 6.3 \\
\hline & $15-30$ & 0.9 & 1.9 & 6.2 \\
\hline & $55-65$ & 0.8 & 2.2 & 6.3 \\
\hline & $95-105$ & 0.8 & 2.3 & 6.3 \\
\hline \multirow[t]{5}{*}{ City tap water and no zeolite } & $0-5$ & 3.1 & 1.6 & 6.6 \\
\hline & $5-15$ & 0.8 & 1.2 & 6.3 \\
\hline & $15-30$ & 0.5 & 1.7 & 6.2 \\
\hline & $55-65$ & 0.8 & 2.2 & 6.2 \\
\hline & $95-105$ & 0.9 & 2.3 & 6.2 \\
\hline
\end{tabular}

These results suggest that major ions other than $\mathrm{Na}^{+}$were leached from the soil. The introduction of CBNG co-produced water rich in $\mathrm{NaHCO}_{3}$ may have also resulted in the precipitation of $\mathrm{Ca}^{2+}$ and $\mathrm{Mg}^{2+}$ salts in the soil to insoluble carbonates, reducing the amount of soluble salts (and EC) in the soil. The EC values for the city water boreholes without zeolite were greater than the CBNG co-produced water without zeolite suggesting that soluble salts were leached from the upper layers of soil as a result of the application of city water.

\section{Conclusions}

Laboratory studies with BR-zeolite indicated the adsorption of $\mathrm{Na}^{+}$on BR-zeolite followed the Langmuir adsorption model with differences in sorption characteristics using $\mathrm{NaHCO}_{3}$ and $\mathrm{NaCl}$. Adsorption kinetic studies found $\mathrm{Na}^{+}$was inversely related to the size of the zeolite particles with significantly greater adsorption for

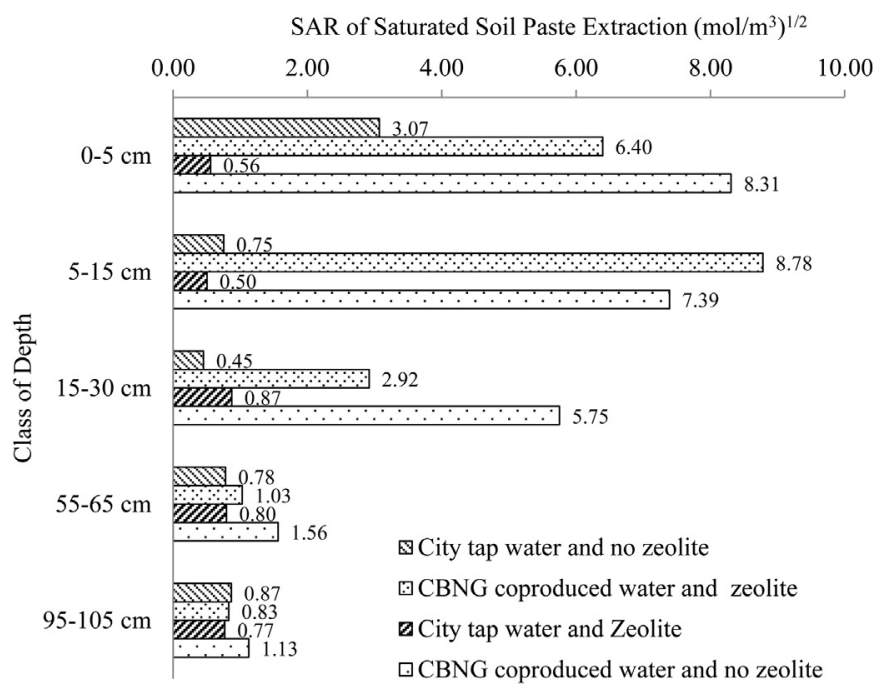

Fig. 8. Distribution of SAR as a function of depth for different experimental conditions. 
Electrical Conductivity EC (dS/m)



Fig. 9. Distribution of soil EC as a function of depth for different experimental conditions.

smaller particles. Results of the field demonstration suggest that BR-zeolite is capable of mitigating some of the soil permeability effects caused by high SAR. Infiltration rates were similar for the city water boreholes with and without zeolite. However, the CBNG co-produced water boreholes showed a significant difference relative to zeolite with much higher infiltration rates for the boreholes containing zeolite. Post field demonstration soil analyses revealed that SAR and $\mathrm{pH}$ values decreased with depth while the EC increased. The soil analyses suggest that the infiltration effects resulted from relatively high $\mathrm{Na}^{+}$concentrations and SAR in the coproduced water. Although the results are encouraging and suggest that treatment with BR-zeolite can be a viable method for mitigating the effects that high sodicity CBNG co-produced water, further research is necessary to evaluate the feasibility of zeolite lined evaporation ponds for the management of CBNG co-produced water.

\section{References}

Airoldi, C., Critter, S.A.M., 2003. Adsorption-desorption processes of calcium on Brazilian soils. Geoderma 111 (1-2), 57-74.

Al-Busaidi, A., Yamamoto, T., Inoue, M., Eneji, A.E., Mori, Y., Irshad, M., 2008. Effects of zeolite on soil nutrients and growth of barley following irrigation with saline water. In: Paper Presented on the 3rd International Conference on Water Resources and Arid Environments (2008) and the 1st Arab Water Forum.

Bresler, E., McNeal, B.L., Carter, D.L. (Eds.), 1982. Saline and Sodic Soils: Principles, Dynamics, Modelling. Springer, Berlin, Heidelberg, New York.

Bureau of Land Management (BLM), 2002. Powder River Basin Oil \& Gas EIS Technical Report - Grown Water Modeling. BLM Field Office, Buffalo, WY.

Burrow, D.P., Surapaneni, A., Rogers, M.E., Olsson, K.A., 2002. Ground water use in forage production: the effects of saline-sodic irrigation and subsequent leaching on soil sodicity. Aust. J. Exp. Agric. 42, 237-247.

Colella, C., 1996. Ion exchange equilibria in zeolite minerals. Mineralium Deposita 31, 554-562.

Department of Energy (DOE), 2008. Research and Development Concerning Coal Bed Natural Gas. DOE Award No. DE-FC26-06NT15568. Report submitted by
William D. Ruckelshaus Institute of Environment and Natural Resources, University of Wyoming, Department 3971.

Eyde, T.H., Holmes, D.A., 2006. Zeolites. In: Kogel, J.E., Trivedi, N.C., Barker, J.M., Krukowski, S.T. (Eds.), Industrial Minerals and Rocks, seventh ed. Society for Mining, Metallurgy, and Exploration Inc, Littleton, CO.

Fetter, C.W., 2001. Applied Hydrogeology, fourth ed. Prentice-Hall, Upper Saddle River, NJ.

Ganjegunte, G.K., King, L.A., Vance, G.F., 2004. Impacts of land application of salinesodic coalbed methane water on soil physical and chemical properties in Wyoming. In: Proceedings of the National Meeting of the American Society of Mining and Reclamation/West Virginia Surface Mine Drainage Task Force, April 18-24, 2004, Morgantown, WV, USA, pp. 720-736.

Ganjegunte, G.K., Vance, G.F., King, L.A., 2005. Soil chemical changes resulting from irrigation with water coproduced with coalbed natural gas. J. Environ. Qual. 34, 2217-2227.

Ganjegunte, G.K., Vance, G.F., Gregory, R.W., Urynowicz, M.A., Surdam, R.C., 2011 Improving saline-sodic coalbed natural gas water quality by natural zeolites. J. Environ. Qual. 40, 57-66.

Huang, F.Y.C., Natrajan, P., 2006. Feasibility of using natural zeolites to remove sodium from coalbed methane-produced water. J. Environ. Eng. 132 (12), 16441650.

Inglezakis, V., 2005. The concept of "capacity" in zeolite ion exchange systems J. Colloid Interf. Sci. 281, 68-79.

Jackson, R.E., Reddy, K.J., 2007. Geochemistry of CBNG produced water in the Powder River Basin: salinity and sodicity. Water Air Soil Pollut. 184, 49-61.

Johnston, C.R., Vance, G.F., Ganjegunte, G.K., 2008. Irrigation with coalbed natural gas coproduced water. Agric. Water Management 95, 1243-1252.

Johnston, C.R., Vance, G.F., Ganjegunte, G.K., 2011. Soil Property Changes Following Irrigation with CBNG Water: Water Treatments, Soil Amendments and Land Suitability. Land Degradation and Management Wiley Online Library (wileyonlinelibrary.com). http://dx.doi.org/10.1002/ldr.1132.

Minhas, P.S., Naresh, R.K., Chauhan, C.P.S., Gupta, R.K., 1994. Field determined hydraulic properties of a sandy loam soil irrigated with various salinity and SAR waters. Agric. Water Management 25, 97-108.

Mumpton, F.A., 1999. La roca Magica: uses of natural zeolites in agriculture and industry. In: Proceedings of the National Academy of Sciences of the U.S.A, vol 96, pp. 3463-3470.

Pansini, M., 1996. Natural zeolites as cation exchangers for environmental protection. Mineralilum Deposita 31 (6), 563-575.

Payne, A.A., 2004. Surface Water Hydrology and Shallow Groundwater Effects of Coalbed Methane Development, Upper Beaver Creek Drainage, Powder River Basin. Department of Geology and Geophysics, University of Wyoming, Wyoming, M.S.. Thesis.

Pratt, P.F., Saurez, D.L., 1990. Irrigation water quality assessments. In: Tanji, K.K. (Ed.), Agricultural Salinity Assessment and Management. American Society of Civil Engineers, New York, pp. 221-226.

Quirk, J.P., 1971. Chemistry of saline soils and their physical properties. In: Talsma, T. Philip, J.R. (Eds.), Salinity and Water Use. Macmillan, New York, pp. 79-91.

Rice, C.A., Ellis, M.S., Bulluck Jr., J.H., 2000. Water Co-produced with Coalbed Methane in the Powder River Basin, Wyoming. Preliminary compositional data. U.S. Geological Survey Open File Report 00-372.

Diagnosis and improvement of saline and Alkali soils. In: Richards, L.A. (Ed.), USDA Handbook 60 et al., 1984 Agriculture Handbook 60, Washington D.C.

Shainberg, I., Letey, J., 1984a. Response of soils to sodic and saline conditions. Hilgardia $61,21-57$.

Shainberg, I., Letey, J., 1984b. Response of soils to sodic and saline conditions. Hilgardia 52, 1-57.

United States Antimony Corporation, 2009. Bear River zeolite specifications. from http://www.bearriverzeolite.com/ (accessed 12.05.09.).

United States Department of Agriculture (USDA), 1954. Diagnosis and Improvement of Saline and Alkali Soils. Agriculture Handbook 60. United States Salinity Laboratory, Riverside, CA.

Vance, G.F., King, L.A., Ganjegunte, G.K., 2008. Soil and plant responses from land application of saline-sodic waters: Implications of management. J. Environ. Qual. 37, 139-148.

Warrance, N.J., Bauder, J., Pearson, K.E., 2001. Salinity and Sodicity Flooding Tolerance of Selected Plant Species of the Northern Cheyenne Reservation. Department of Land Resources and Environmental Sciences, Montana State UniversityBozeman. http://waterquality.montana.edu/docs/methane/cheyenne.html.

Wingenfelder, U., Hansen, C., Furrer, G., Schulin, R., 2005. Removal of heavy metals from mine waters by natural zeolites. Environ. Sci. Technol. 39 (12), 4606-4613.

Wyoming Oil and Gas Conservation Commission (WOGCC), 2012. Data for coalbed natural gas production in the Powder river basin. from: http://wogcc.state.wy. us/coalbedchart.cfm (accessed 02.02.12.).

Zhao, H., Vance, G.F., Ganjegunte, G.K., Urynowicz, M.A., 2008. Use of zeolites for treating natural gas coproduced waters in Wyoming, USA. Desalination 228, 263-276.

Zhao, H., Vance, G.F., Urynowicz, M.A., Gregory, R., 2009. Integrated treatment process using a natural Wyoming clinoptilolite for remediating produced waters from coalbed methane natural gas operations. Appl. Clay Sci. 42 (3), $379-385$. 